of self", with whose help "political goals can be realized in a considerably more 'effective' way via individual 'self-realizations'”64 (ibid.: 30 ) than through explicitlegal limitations of individual freedom.

All in all, this broad understanding of social, cultural and political performativities provides a suitable bracket for conceptually underpinning the chapters in this volume and emphasizing their coherence despite the considerable variety of subject matters addressed in the individual case studies: chapter 5 examines technologies of self; chapter 3 deals with technologies of government; in addition, a further chapter (4) is concerned with apparatuses that are marked by interstices, fuzzy zones and blurrings of these effects. In this way the ongoing constitutive processes of identity construction - attributions (identification by/of) and appropriations (identification with) - can be presented with a clearer structure in terms of concepts and empirics in their dialectic with spatial constructions in border spaces.

\title{
2.4 Methodology and Situative Interdisciplinarity
}

\section{Christian Wille}

The investigation of constructions of space and identity in this volume focuses on social practices and on specific sub-aspects linked to them (e.g. bodies, artefacts, spatial networks of relationships, logics of power, attributions of signification with their specific differentiations and situatedness). If we take practices as the point of departure of our considerations, this raises the question of how these can be investigated in terms of research practice. In this context, Reckwitz (2008: 195) points out that the presence of the researchers in situ is only possible to a limited extent. Even though current practices are directly accessible via the present and perceivable materiality of bodies and artefacts, interpretations of meaning through visual and auditive perception remain concealed. These need to be deduced indirectly, "i.e. one has to draw conclusions about the implied schemata from explicit statements, actions, ways of dealing with things etc." ${ }^{\prime 65}$ (ibid.: 196). Here, the qualitative interview seems to be a suitable method for revealing verbally formulated interpretations of meaning. In the case of past practices the issue of direct access to practices becomes more acute: the materiality of the bodies and

64 | Personal translation of: [die] "Ersetzung des Politischen durch das Persönliche" [plädiert, sondern für] "eine andere Form von Politik und den Entwurf neuer Selbsttechnologien”, [mit Hilfe derer] "politische Ziele [sich] wesentlich 'ökonomischer' mittels individueller 'Selbstverwirklichung' realisieren lassen."

65 | Personal translation of: “[...] das heißt, aus expliziten Äußerungen, Handlungen, Umgangsweisen mit Dingen usw. muss auf die impliziten Schemata rückgeschlossen werden."

E-Book von Christian Wille, christian.wille@uni.lu 27.01.2016 17:18

Copyright 2016, transcript Verlag, Bielefeld 
artefacts involved in the practices is not open to direct scrutiny, even though it is possible to make observations via media (e.g. film, photography). Here too, interpretations of meaning can only be identified indirectly (e.g. via interviews of contemporary witnesses). Textanalytical processes in particular can be useful here, if for instance written descriptions of practices or ego documents (e.g. letters, diaries) are examined for the subjectifications and subjectivations 'contained in them'.

The above considerations are intended to sensitize us to the fact that the investigation of spatial and identity constructions - which are always only temporary results of practices - almost unavoidably depends on working with data about the practices and their sub-aspects. This is also true for the case studies in this volume, although we do not differentiate here between present and past practices, but rather between three key methodological approaches that allow us to reconstruct the practices of institutions, media and everyday life together with the constructions of space and identity contained in them.

These firstly concern textanalytical processes for examining (non)standard written cultural manifestations (e.g. exhibition catalogues, films, advertisements, virtual environments, gravestones, newspaper articles etc.). They include further approaches from content and discourse analysis as well as semiotics and will be discussed specifically in the corresponding case studies.

Secondly they involve a quantative survey and a series of qualitative interviews with persons in Luxembourg and its adjoining regions. A special feature of this second methodological approach is the cross-border character of the surveys in Luxembourg, Germany, France and Belgium, and the authors' interdisciplinary modus operandi in developing the survey tools and conducting the survey as such. The forms of survey with a more social-scientific approach were used in different ways in the case studies - depending on the epistemic interest - and the collected data were partly combined with each other. This permitted to bring together various aspects of a particular phenomenon and thus expand and complete the perspective on the subject matter under scrutiny.

Besides the techniques of collecting data mentioned above, we will, thirdly, take a closer look - as an auto-reflexive method - at the way the contributors to this volume collaborated. Representing different disciplines of the humanities, they met regularly over a period of three years, shared and discussed their insights and thoughts with the aim of looking beyond the limits of their own discipline and, guided by their subject, setting foot on terrain 'alien' to their field (see chapter 1). One of the concerns of this research context was therefore the collaboration between scholars of different disciplines, which in general is subsumed under the term of interdisciplinarity. This term is itself, however, rarely the subject of reflection, and interdisciplinary research is often regarded as a repository for researchers who were "not quite able to gain a foothold" ${ }^{66}$ elsewhere (Löffler

66 | Personal translation of: "[...] nicht recht Fuß fassen konnten.”

E-Book von Christian Wille, christian.wille@uni.lu 27.01.2016 17:18

Copyright 2016, transcript Verlag, Bielefeld 
2010: 158). This was the reason for a number of authors to take a critical look at 'interdisciplinarity' and develop the concept of 'situative interdisciplinarity' as a common guideline for their collaboration.

In the following we will comment on some research-practical aspects of the quantitative survey and the series of qualitative interviews as well as the corresponding samples, and discuss how we handled the cross-disciplinary collaboration in the making of this volume.

\subsubsection{Quantitative Survey}

One of the major sources of data for the case studies of this volume is the quantitative representative survey. A total of 3,300 people were interviewed in the sovereign nation state of Luxembourg, in the bordering areas of the federal states of Saarland and Rhineland-Palatinate (Germany), and the regions of Lorraine (France) and Wallonia (Belgium). Considering the issues investigated in this volume, we for the most part interviewed people living in the border region in relative proximity to a national border. The aim was to collect data about various practices and evaluate these under the aspect of the construction of space and identity in the context of the border. The questionnaire used for this and developed by the various disciplines is subdivided in a number of subjects ${ }^{67}$ that were operationalized with the help of semi-open and closed-ended questions. Due to Luxembourg's multilingualism and the different languages spoken in the neighbouring regions (see section 5.9) it was necessary to translate the questionnaire (as well as the interview guideline of the qualitative survey) into Luxembourgish, German, French and English. However, a correlation of the survey results was only possible if the meanings of the subjects discussed and key terms matched in the multlingual survey tools. This refers to the socio-cultural spectrum of lexical elements' meaning which, in the translation of survey tools, raises the question whether and in how far the target language possesses an equivalent phrasing that precludes semantic shifts. An equivalence test can be performed via re-translation, but also via discursive procedures where the specific translations are critically discussed with persons sensitive to equivalences. Since a number of authors participating in this volume are bilingual, we applied the discursive procedure for testing the equivalence of the survey tools.

67 | These include: socio-demographic information, leisure time and contacts, shopping, household, political life, communication and language, Greater Region and mobility, men and women. The questionnaire is listed in the data collection of the quantitative survey and can be accessed at the library of the University of Luxembourg.

E-Book von Christian Wille, christian.wille@uni.lu 


\begin{tabular}{|l|l|l|l|}
\hline & $\mathrm{n}$ & $\begin{array}{l}\text { Total } \\
\text { Sample in } \\
\%\end{array}$ & $\begin{array}{l}\text { Sample of Respondents in } \\
\text { Border Area in \% }\end{array}$ \\
\hline $\begin{array}{l}\text { Respondents in } \\
\text { Luxembourg }\end{array}$ & I,02I & 30.9 &. \\
\hline $\begin{array}{l}\text { Respondents in } \\
\text { Border Area }\end{array}$ & 2,279 &. & 100 \\
\hline Saarland & 314 & 9.5 & 13.8 \\
\hline Lorraine & 867 & 26.3 & 38 \\
\hline $\begin{array}{l}\text { Rhineland- } \\
\text { Palatinate }\end{array}$ & 581 & 17.6 & 25.5 \\
\hline Wallonia & 517 & 15.7 & 22.7 \\
\hline Total & 3,300 & 100 &. \\
\hline
\end{tabular}

Table 1: Sample of the quantitative survey (overview) (University of Luxembourg, IDENT2 2012/2013)

The collection of the samples in Luxembourg and the neighbouring regions was entrusted to a Luxembourg survey institute, which was also responsible for carrying out the representative survey. Between December 2012 and February 2013 a total of 1,021 persons aged 16 and above living in Luxembourg and 2,279 persons of the same age segment living in the neighbouring regions were questioned. Almost two fifths of the respondents living in the border area are located in Lorraine, one quarter in Rhineland-Palatinate, slightly more than a fifth in Wallonia and $14 \%$ in the Saarland (see Table 1). The survey was carried out via internet (computer-assisted web interviews) and the subsamples were weighted according to different features: the sample in the Grand Duchy according to the variables of region of residence, age, nationality, gender and (un)employment; persons living in the border area according to region of residence, age and gender. The data were analysed with the procedures of descriptive and inductive statistics. ${ }^{68}$

68 | The collected data can be accessed in the library of the University of Luxembourg. 


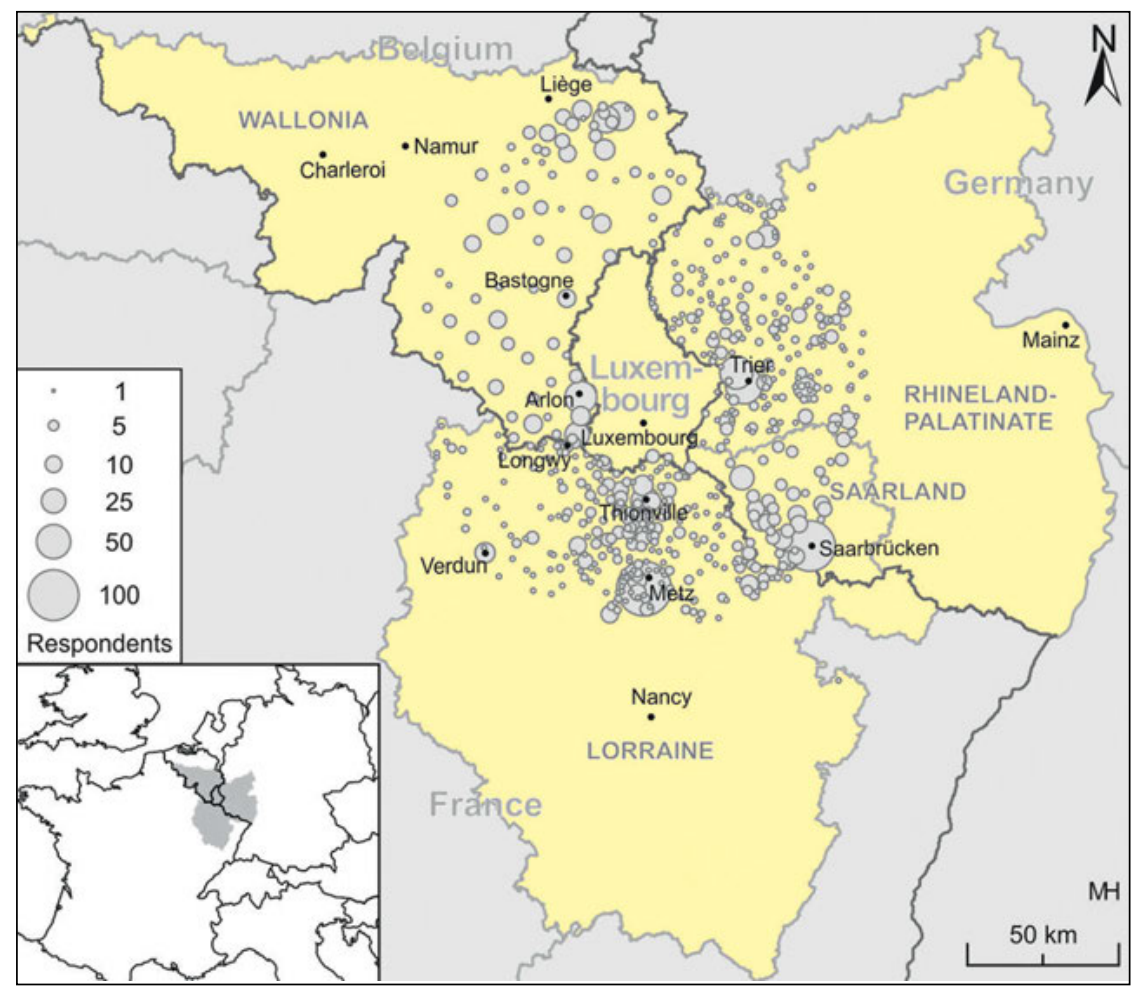

Figure 1: Distribution of the places of residence of the respondents in the quantitative survey in the border area (overview) (University of Luxembourg, IDENT2 2012/2013) (design: Christian Wille, realization: Malte Helfer)

A closer look at the the geographic distribution of the places of residence of persons living in the border area shows that they don't live further away than $50 \mathrm{~km}$ from a national border and the majority of them close to a national border (see Fig. 1 and 2). Thus the majority of the survey respondents in Lorraine live in northern Lorraine immediately bordering Luxembourg and Belgium; more than two fifths (43\%) live in Thionville (28 \%) and in Briey ( $15 \%$ ), both located close to the border. A further $17 \%$ live in eastern Lorraine close to the border to Germany, distributed across Forbach (10\%), located directly on the border, and Boulay (7\%). $37 \%$ of the respondents live further in the hinterland of the Metz agglomeration, of these $13 \%$ in the town of Metz , $6 \%$ in Verdun and $18 \%$ in the Metz region (18\%). Only $2 \%$ live in Nancy and in the Nancy agglomeration. $50 \%$ of the respondents in Wallonia have their place of residence in the province of Luxembourg bordering France and Luxembourg. The majority of them live in the border town of Arlon (16\%), followed by Virton (9\%), Neufchâteau (9\%), Bastogne (9 \%) and further in the hinterland around Marche-en-Famenne (7\%). $42 \%$ of the respondents in Wallonia live in the province of Liège which borders Germany and Luxembourg. 
There they mainly reside in the cities of Verviers (27\%) and Liège (13\%) as well as in Huy (2\%). Further $6 \%$ live in the town of Dinant which is in the province of Namur and lies on the border to France. More than half of the respondents (57\%) in Rhineland-Palatinate are distributed across the three communities bordering on Luxembourg. They include Trier-Saarburg (26\%), Bitburg-Prüm (22\%) and the city of Trier (9\%). As many as $22 \%$ of the respondents are domiciled in the rural district of Bernkastel-Wittlich, despite being somewhat further away from the border, followed by the community of Vulkaneifel (12\%). The majority of the survey respondents in the Saarland lives in the west and the north of the federal state, where it borders France and Luxembourg. $42 \%$ live in the regional association Saarbrücken and along the river Saar in the district of Saarlouis (30\%) as well as in the rural district of Merzig-Wadern (18\%). Only 7 and $3 \%$ of the respondents have their home in the rural districts of St. Wendel and Neunkirchen which are further away from the border.

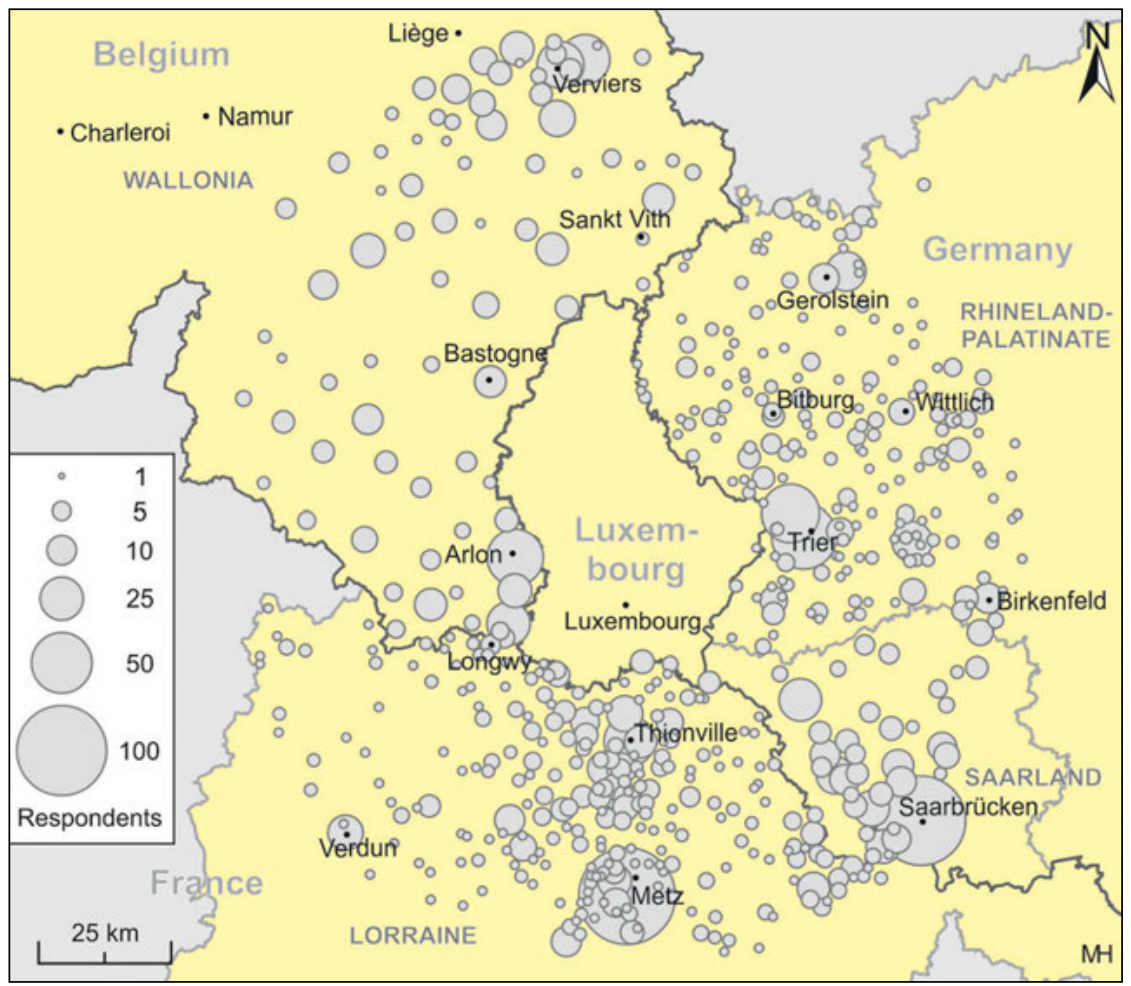

Figure 2: Distribution of the places of residence of the respondents in the quantitative survey in the border area (detailed view) (University of Luxembourg, IDENT2 2012/2013) (design: Christian Wille, realization: Malte Helfer) 


\subsubsection{Qualitative Interviews}

Based on the quantitative representative survey, in spring 2013 in-depth interviews were conducted with residents of Luxembourg and in the neighbouring regions who had agreed to do so in the preceding questionnaire. ${ }^{69}$ The aim was to collect, via the wide ranging series of interviews, qualitative data about practices and particularly about the attributions of meaning connected to them for which a standardized procedure is less suited. The qualitative interviews were therefore carried out with a semi-standardized interview guide with fully phrased questions and conversation-generating impulses. ${ }^{70}$ In addition, the authors of the present volume, who contributed the individual questions to this guide, were asked to briefly state the epistemic interest and purpose of each question. These were then explained and discussed internally. This made it possible to proceed in a cooperative fashion which would allow the interviewers to also prepare for the interviews by additionally familarizing themselves with the 'thrust' of their colleagues' questions. For this purpose the interviewers recast the detailed interview guide into bullet points, which permitted flexible and largely open interviewing.

It was not the aim of the interview series to establish frequencies, but rather develop a more detailed understanding of processes of the construction of space and identity in the context of the border. We were thus not concerned with acquiring a random sample in order to make subsequent inferences on a population, but rather with studying individual and varied cases, in order to capture information about practices with their specific subaspects. This required a calculated compilation of samples specified according to gender, age, nationality and level of education. Finally, on this basis and minus cases that did not materialize, 47 persons in the area under consideration were interviewed, 24 of them in Luxembourg and 23 in the border area (see Table 2).

69 In their cases studies, some authors in this volume draw additionally on their own and specifically indicated interview series (including expert interviews).

$\mathbf{7 0}$ | The abridged interview guide is included at the end of this volume. 


\begin{tabular}{|c|c|c|c|c|c|c|}
\hline & $\begin{array}{l}\text { Luxem- } \\
\text { bourg }\end{array}$ & $\begin{array}{l}\text { Border } \\
\text { Area }\end{array}$ & $\begin{array}{l}\text { of these in } \\
\text { Rhineland- } \\
\text { Palatinate }\end{array}$ & $\begin{array}{l}\text { of these } \\
\text { in the } \\
\text { Saarland }\end{array}$ & $\begin{array}{c}\text { of these } \\
\text { in Lorraine }\end{array}$ & $\begin{array}{l}\text { of these } \\
\text { in } \\
\text { Wallonia }\end{array}$ \\
\hline \multicolumn{7}{|l|}{ Gender } \\
\hline Men & 14 & 12 & 2 & 4 & 3 & 3 \\
\hline Women & 10 & 11 &. & 3 & 4 & 4 \\
\hline \multicolumn{7}{|l|}{ Age groups } \\
\hline $15-24$ & 3 & . & . & . & . & . \\
\hline $25-34$ & 4 & 6 & . & 2 & 2 & 2 \\
\hline $35-44$ & 2 & 7 &. & 1 & 2 & 4 \\
\hline $45-54$ & 6 & 6 & 1 & 2 & 2 & 1 \\
\hline $55-64$ & 4 & 3 & 1 & 1 & 1 & . \\
\hline $65-74$ & 3 &. & . & . & . & . \\
\hline $75-84$ & 2 & . & . & . & . & . \\
\hline $85-94$ & . & 1 & . & 1 & . & . \\
\hline \multicolumn{7}{|l|}{ Status } \\
\hline $\begin{array}{l}\text { Non- } \\
\text { foreigner }\end{array}$ & 12 & 17 & 2 & 6 & 6 & 3 \\
\hline Foreigner & 12 & 6 & . & 1 & 1 & 4 \\
\hline \multicolumn{7}{|l|}{$\begin{array}{l}\text { Level of } \\
\text { education* }\end{array}$} \\
\hline ISCED $_{1}$ & 2 & . & . & . & . & . \\
\hline ISCED 2 & 5 & 5 & 1 & 3 & . & 1 \\
\hline ISCED 3 & 7 & 5 & 1 &. & 2 & 2 \\
\hline$I$ SCED $_{4}$ & 2 & 3 &. & 1 & 2 &. \\
\hline $\begin{array}{l}\text { ISCED } 5 \\
\text { and } 6\end{array}$ & 7 & 9 & $\cdot$ & 3 & 3 & 3 \\
\hline $\begin{array}{l}\text { No } \\
\text { response }\end{array}$ & 1 & 1 & . & . & . & 1 \\
\hline Net sample & 24 & 23 & 2 & 7 & 7 & 7 \\
\hline
\end{tabular}

Table 2: Sample of the qualitative survey (University of Luxembourg, IDENT2 2012/2013) *According to International Standard Classification of Education (ISCED)

The interviews were conducted by the authors according to language preferences and availability and took place by appointment at the home of the interviewees and frequently in the mornings or evenings. In a conversation usually lasting between one and one and a half hours, various subject areas were discussed following the interview guide, and the interviewees had the opportunity to express themselves freely - but within a certain thematic frame of reference. In this way the interviewees' interpretations and reactions were collected and aspects the researchers had not anticipated were allowed to emerge. Since what concerns us in this volume are the contents of the interviews and not their linguistic form, we 
employed, for the processing of the digitally recorded interviews, the transcription procedure of the standard language conversion (see Mayring 2002: 91) that consists in minimal emendations of syntactical errors and in streamlining the speech flow. The transcription of the interviews into Luxembourgish, German, French and English was entrusted to transcriptors specifically employed for this purpose. The interview transcripts were then computerized and evaluated via deductive-selective coding as well as inductive-open coding. This means, we first performed a broad coding consisting in assigning responses from the interviews to the subject areas discussed in them. Using the emerging code tree as a basis, the authors of the individual interview questions proceeded to fine-code, with an inductive-open coding, interviewees' answers by argumentative units of signification. The researchers also took responses into account that referred to their colleagues' subject areas in order to be able to record chains of reasoning in the empirical material that cut across thematic fields.

\subsubsection{Cross-Disciplinary Collaboration ${ }^{71}$}

In academia there are few terms where the discrepancy between frequency of use and theoretical reflection is so extreme as that of interdisciplinarity (see Jungert 2010: 1). It has become a fixture of rhetorics accompanying scientific projects and its inflationary use reinforces the frequently adopted stance that interdisciplinary research supposedly can't be expected to yield any real insights. In order not to risk letting the interdisciplinary or cross-disciplinary collaboration deteriorate to an empty phrase, a number of the contributors to this volume have formed a workgroup to examine the potential and the risks of interdisciplinarity (see chapter 1). Their aim was to systematize the term and the concepts linked with it and develop a common guideline for the work in the framework of the present volume.

When dealing with interdisciplinarity, one first needs to clarify what is to be understood under disciplinarity. In this context Sabine Hark (2005) draws attention to the concept of discipline/disciplinarity which comprises two dimensions, a discipline generating one, and a disciplining one. Disciplines - as a basis for the organization and structuring of scientific knowledge - should here not be understood statically but rather as dynamic points of intersection of different theoretical-methodological paradigms. Hark defines disciplines as complex bundles of relationships, drawing on Foucault's concept of discursive formation. It is the relationships "between institutions, economic and societal processes, forms of behaviour, systems of norms, techniques, classification systems and manners of characterization"72 (Hark 2005: 71) that constitute a discipline. Accordingly,

71 This section was written in collaboration with Brigitte Batyko, Heike Mauer, Agnès Prüm and Rachel Reckinger.

72 | Personal translation of: "[...] zwischen Institutionen, ökonomischen und gesellschaftlichen Prozessen, Verhaltensformen, Normsystemen, Techniken, Klassifikationstypen und

E-Book von Christian Wille, christian.wille@uni.lu 27.01.2016 17:18

Copyright 2016, transcript Verlag, Bielefeld 
the discipline-generating effect manifests itself in the continued updating of this network of relationships. From this social-emergent and relational perspective, discipline can be seen as an ensemble of heterogenous elements such as communities of communication, objects of knowledge and institutions. Hark explains the disciplining dimension (2005: 75ff.) by highlighting disciplines as political institutions. This involves three functions: (1) the production of knowledge, which is connected to the production of (in)valid statements, knowable objects, hierarchically ordered subjects (e.g. academic degrees) or practices of knowledge (e.g. plenary lectures); (2) the regulation of knowledge which takes effects when determining the recognized subject areas as well as the cognitive structure of the actors and their academic practices; (3) the reproduction of knowledge which ensures the continuity in the academic field via the transmission of knowledge and the socialisatory exercising of academic practices. The disciplining dimension is particularly prominent in the reproductive function, when, for example, disciplines organize and classify what is worth knowing and thus regulate what is remembered and what is forgotten.

Taking these considerations into account a discipline can be seen as a space in the academic field which regulates and reproduces itself via specific practices of knowledge and the involved objects, schools of thought, traditions of theory and methodology as well as embedded power relations and self-conceptions. These aspects go generally unquestioned and their interaction is constitutive for individual disciplines. However, they become untenable in research contexts in which different disciplines work together. The fault lines and thus the boundaries of the discipline begin to show up in a praxeological sense where practices of knowledge are no longer self-evidently effective, where formerly constitutive relationships need to be explicitly explained, and previously unquestioned foundations of signification are cast into doubt. Figuratively speaking we are then dealing with a 're-wiring' of complex bundles of relationships or ensembles of heterogenous elements which as we shall see - can vary in intensity, irritation and innovation.

A glance into the relevant literature shows that besides the term of interdiscipliarity there exist other competing terms which are not used consistently and partly overlap in their meaning. When systematizing terms of interdisciplinarity and related concepts we are thus faced with a problem of demarcation. We will therefore introduce the term of 'cross-disciplinary collaboration'73, in order to be able to topicalize different forms of collaboration under one umbrella term. For this we have chosen two approaches: in a first step, we will establish which terms are used in research funding for cross-disciplinary collaboration and what significance they have there. In a second step, the relevant concepts are presented synoptically and classified by structural criteria.

Charakterisierungsweisen.”

73 | Personal translation of: "Disziplinenübergreifende Zusammenarbeit."

E-Book von Christian Wille, christian.wille@uni.lu 27.01.2016 17:18

Copyright 2016, transcript Verlag, Bielefeld 
We will thus first examine whether cross-disciplinary collaboration plays a role in funding policies and which terms are used in each case. To this end, calls for proposals of specific funding programmes in the field of humanities and science as well as annual reports (2012) of national and European funding institutions and agencies were analysed (see Table 3).

\begin{tabular}{|c|c|c|}
\hline Level & $\begin{array}{l}\text { Institutions/Funding } \\
\text { Agencies }\end{array}$ & Funding Programmes \\
\hline Regional & University of Luxembourg & Intra-University Project Funding \\
\hline \multirow[t]{4}{*}{ National } & $\begin{array}{l}\text { Luxembourg: Fonds } \\
\text { National de la Recherche } \\
\text { (FNR) }\end{array}$ & $\begin{array}{l}\text { FNR: CORE, INTER, ATTRACT, AFR, } \\
\text { PEARL }\end{array}$ \\
\hline & $\begin{array}{l}\text { Germany: Deutsche } \\
\text { Forschungsgemeinschaft } \\
\text { (DFG) }\end{array}$ & $\begin{array}{l}\text { DFG: Schwerpunktprogramme, } \\
\text { Graduiertenkollegs, Sonderforschungsbereiche, } \\
\text { DFG Forschungszentren, Forschergruppen, } \\
\text { Kolleg-Forschergruppen, Aufbau } \\
\text { internationaler Kooperationen } 75\end{array}$ \\
\hline & $\begin{array}{l}\text { France: Agence nationale de } \\
\text { la Recherche (ANR) }\end{array}$ & $\begin{array}{l}\text { ANR: various thematic calls: Biologie-Santé, } \\
\text { Energie Durable, Environnement et Ressources } \\
\text { Biologiques, Ingénierie, Procédés et Sécurité, } \\
\text { Partenariats et compétitivité, Programmes } \\
\text { transdisciplinaires, Recherches exploratoires et } \\
\text { émergentes, Sciences Humaines et Sociales }{ }^{76}\end{array}$ \\
\hline & $\begin{array}{l}\text { Belgium: Fonds de la } \\
\text { Recherche Scientifique- } \\
\text { FNRS (F.R.S.-FNRS) }\end{array}$ & $\begin{array}{l}\text { F.R.S.-FNRS: Appels 'Crédits et projets', } \\
\text { FRESH II - Recherche collaborative en } \\
\text { sciences humaines et sociales. }\end{array}$ \\
\hline European & European Commission & $\begin{array}{l}\text { ERC grants: Proof of Concept, Synergy } \\
\text { Grant, Advanced Grant, Starting Grant, } \\
\text { Consolidator Grant } \\
\text { - Seventh Framework Programme (FP7): } \\
\text { specific programmes 'Cooperation' and } \\
\text { 'People' (Marie Curie Actions) } \\
\text { - Horizon 2020: Programmes 2014-2015 }\end{array}$ \\
\hline
\end{tabular}

Table 3: Reviewed calls for proposals by selected funding agencies (July 2013)

74 | Priority Programmes, Research Training Groups, Collaborative Research Centres, DFG Research Centres, Research Units, Humanities Centres for Advanced Studies, Initiation of International Collaboration.

75 | Biology and Health, Sustainable Energy, Environment and Biological Resources, Engineering, Processes and Security, Partnership and Competitiveness, Transdisciplinary Programmes, Exploratory and Emerging Research, Social Sciences and Humanities. 
The analysis of the calls for proposals was conducted in three languages per search query of frequently used terms in connection with cross-disciplinary collaboration. ${ }^{76}$ The most frequently found terms were disziplinär/interdisziplinär, disciplinary/disciplinarity, interdisciplinary/interdisciplinarity, interdisciplinaire/ interdisciplinarité and frontier research, indicating a priori that the term 'interdisciplinarity' was widely used. In addition, we noticed that in the calls for proposals there was no further explanation what exactly the funding institutions meant with the searched terms - and thus with cross-disciplinary collaboration. This confirms the impression that the term of interdisciplinarity and related concepts remain blurred and are often mere accompanying rhetorics. All the more important to address this very diverse field and structure it along the relevant terms.

Multi-/Pluridisciplinarity: The term of multidisciplinarity entered academic language in the 1950 s and refers to the coexistence of disciplines within one subject area. The disciplines involved here each work on a sub-aspect of the common area of investigation which is within 'their' subject matter. In this form of collaboration, common research questions, mutual references or cross-disciplinary efforts to create a synthesis are largely absent. However, in contrast to purely disciplinary research one can assume that the participating disciplines share pertinent information about their work and that there is potential for broadening the perspective on the common field of investigation (see Jungert 2010: 2). The term of pluridisciplinarity is often used synonymously with multidisciplinarity. However, some authors, for instance Jungert (see ibid.) differentiate between these terms and see pluridisciplinarity as a first step of a truly cross-disciplinary collaboration. This involves the intensification of relations between related disciplines via a loose exchange of findings and problems within a common subject area. However, this in general unstructured collaboration has little effect on the subject matters and on the self-concept of the participating disciplines.

Interdisciplinarity: The term 'interdisciplinarity' is the one most frequently used in the context of cross-disciplinary collaboration. This is also confirmed by the analysis of the calls for proposals by national and European research funding (see Table 3). Interdisciplinarity - albeit without further explanation and with varying emphasis - is firmly anchored in these texts. The Luxembourgish and Belgian funding institutions are more reticent about the interdisciplinary character of research projects and merely indicate that interdisciplinary research is desirable. German and French programmes emphasize the interdisciplinary character of projects more frequently and put a stronger focus on the promotion of interdisciplinarity. European funding programmes also welcome and support the

76 | Search terms used in three languages: disziplinär, multi-, inter-, transdisziplinär, Disziplinarität, Multi-, Inter-, Transdisziplinarität, Pionierforschung, disciplinary, multi-, inter-, transdisciplinary, cross-disciplinary, disciplinarity, multi-, inter-, transdisciplinarity, frontier research, inter/cross-faculty, disciplinary boundaries, cross-programme, disciplinaire, multi-, inter-, transdisciplinaire, disciplinarité, multi-, inter-, transdisciplinarité.

E-Book von Christian Wille, christian.wille@uni.lu 27.01.2016 17:18

Copyright 2016, transcript Verlag, Bielefeld 
interdisciplinary orientation of research projects. Here the grants of the European Research Council (ERC) play a particular role because they are expressly designed to promote interdisciplinary project work and so-called pioneer research. The European programme Horizon 2020 likewise clearly emphasizes interdisciplinary research as an important aspect worthy of funding - as the Seventh Framework Programme (FP7) had already done before. While we see that the concept of interdisciplinarity is indeed supported by public funding policies, there is still the impression that it is as yet not really strategically embedded and that the addressees are assumed to have an understanding of interdisciplinarity which is not further specified. This can however differ significantly and - as we shall see - partly show variously large overlaps with related concepts. For a further discussion of the concept of interdisciplinarity we will focus on its complexity and attempt an internal differentiation. Drawing on Löffler (see 2010: 164ff.) and Heckhausen (quoted in Jungert 2010: 4ff.), we will outline a possible spectrum of interdisciplinarities.

- Heckhausen uses the term 'indiscriminate interdisciplinarity' (unterschiedslose Interdisziplinarität) to describe the idea of the studium generale in which various disciplinary contents are 'juxtaposed' to offset high levels of specialization and the narrowing of perspectives that accompany them. Mutual references between the disciplines are not intended here, nor is there any cross-disciplinary collaboration in the area of research.

- 'Nice-to-know interdisciplinarity' (Nice-to-know-Interdisziplinarität), a term coined by Löffler, applies to a situation where the participating disciplines refer to one common subject but where no points of contact or relationships of exchange develop. Nevertheless, research contexts or events with a nice-to-know factor are useful, for instance as a social event in academia for networking or when, in decision-making processes, it is necessary to consider different perspectives on one subject.

- With the term 'pseudo-interdisciplinarity' (Pseudo-Interdisziplinarität), Heckhausen refers to the common assumption that one can already speak of interdisciplinarity when different disciplines work with identical models or methods. This is however in his view not sufficient for bridging differences between the disciplines, for example regarding 'typical' subject domains or levels of theoretical integration.

- 'Auxiliary interdisciplinarity' (Hilfsinterdisziplinarität) is used by Heckhausen to describe the use of methods within one's own discipline that are foreign to it. But, according to Heckhausen, it cannot be described as a true collaboration, since it is merely a matter of treating 'typical' questions within one's own disciplines with the help of 'borrowed' methods.

- The grouping of various disciplines around a common complex of problems or subjects is subsumed by Heckhausen under the term of 'composite interdisciplinarity' (zusammengesetzte Interdisziplinarität). But there is neither an overlap of subject areas of the participating disciplines nor of the methods 
employed. The cohesion of the common research context is in this case only based on the common area of problems and themes.

- 'Supplementary interdisciplinarity' (Ergänzende Interdisziplinarität) is situated, according to Heckhausen, on the fringes of disciplines, where there is in part a real attempt to establish a nexus between the different theoretical approaches.

- For a high degree of interaction between disciplines, Heckhausen uses the term of 'unifying interdisciplinarity' (Vereinigende Interdisziplinarität). This refers to the convergence and synthetization of different disciplinary theories and sets of conceptual and methodological tools.

This cursory synopsis of interdisciplinarities not only addresses different aspects of the research process, it also reveals different forms of disciplinarity that can be located on a continuum between the affirmation and the subversion of disciplinary boundaries. As we shall see, the conceptual understanding of interdisciplinarity that was relevant in the making of this volume refers to a number of the interdisciplinarities featured above.

Transdisciplinarity: The concept of transdisciplinarity, in turn, denotes a form of working where specific issues are addressed together with actors outside academia and where there is an attempt to overcome the specialization of academic knowledge (see Jungert 2010: 6). So this is firstly about crossing the threshold between academia and 'the world outside' in order to find scientific solutions for complex societal problems; and secondly about the questioning of the (disciplinary) order of academic knowledge as such (see Després/Lawrence 2004: 399). Transdisciplinarity also implies a critique of disciplinarity as a specific academic practice and aims at regrouping questions, theories and methods without linking them back to individual disciplines (see Maihofer 2005: 199).

Postdisciplinarity: The concept of postdisciplinarity dissociates itself even more clearly from the dichotomy of academic knowledge production on the one hand and the non-academic knowledge production on the other. Postdisciplinarity aims at a research process that does not commit itself to one or more disciplines regarding subject matter and research questions nor proceeds deductively in the development of theories and solutions. Rather, it is concerned - similar to the transdisciplinary approach - with an inductive-reflective process in which the questions to be examined, methods used and theories and solutions developed are generated (see Maihofer 2005: 201).

The forms of cross-disciplinary collaboration presented above show multiple overlaps. Nevertheless they can be distinguished from each other and classified with the help of specific criteria.

For our essay at systematization (see Fig. 3) we have proceeded from the basis of the criterion of disciplinarity as a continuum explained above which grades forms of cross-disciplinary collaboration where discipline-generating and disciplining mechanisms are (in)effective. Forms of cross-disciplinary collaboration where disciplinarity progressively loses its effect are also marked by increasing

E-Book von Christian Wille, christian.wille@uni.lu 27.01.2016 17:18

Copyright 2016, transcript Verlag, Bielefeld 
complexity. This results from the 'rewiring' of bundles of relationships (between objects, methods, concepts etc.) that exist within and outside of academia.

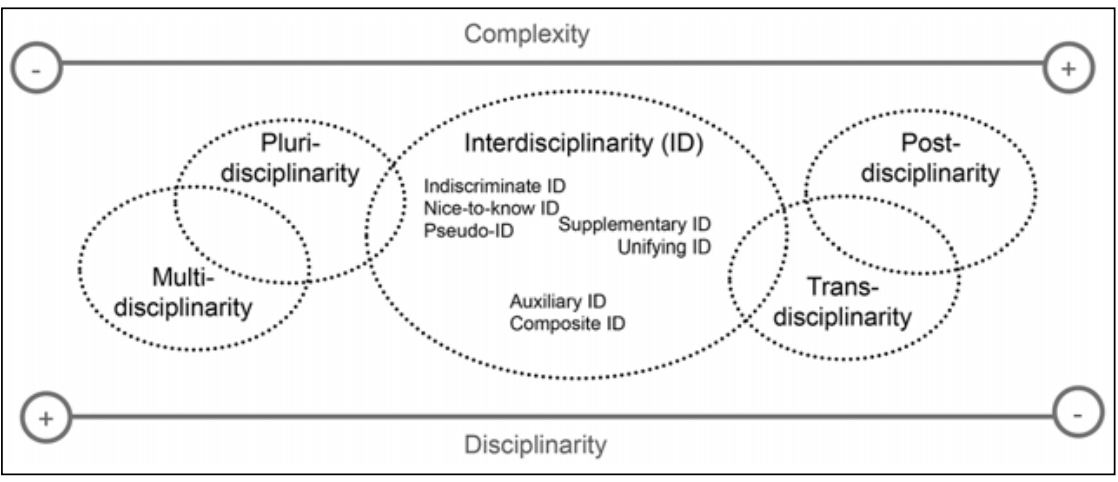

Figure 3: Forms of cross-disciplinary collaboration by the criteria of 'complexity' and 'disciplinarity' (design: Christian Wille)

\subsubsection{Situative Interdisciplinarity}

From the typology of multi-/pluri-/inter-/trans- and postdisciplinarity presented above - as a series of increased complexity with diminishing disciplinarity - we can derive three basic models of cross-disciplinary collaboration:

(1) Cross-disciplinary collaboration as addition should be understood as a collection of different disciplines that work on a common (research) subject and merely share information. In this scientific practice, which would belong to multi- and/or pluridisciplinarity, there is no real exchange and thus no crossing of disciplinary borders.

(2) Cross-disciplinary collaboration as interaction can be found where there is an actual exchange between disciplines grouped around a common (research) topic, but without the participating disciplines 'dissolving'. Here we are dealing with different methods of elaboration of or empirical approaches to a common research question - partly the aim behind the concept of interdisciplinarity - which are linked to each other and promise to yield more insights than would be possible to achieve from only one single disciplinary perspective. Even though the individual disciplines remain for the most part 'untouched', this form of collaboration is potentially prone to critical moments that come to bear in 'disorders' of the familiar research practice and require the participating researchers to display certain social faculties (e.g. tolerance for ambiguity, empathy) in order to be able to put up with them and/or exploit them productively (see Wiesmann/Biber-Klemm et al. 2008: 174ff.).

(3) Qualifying cross-disciplinary collaboration as a synthesis suggests scientific practices that overcome disciplinary and institutional systems in a problem- and/ or solution-oriented way. Similar to the concepts of trans-/postdisciplinarity, here 
the (research) topics as well as the necessary conceptual and methodological tools are not predefined, but rather these are developed in a deductive-recursive procedure - mostly also involving non-academics (see ibid.: 172f.). A prerequisite for this kind of collaboration is a high degree of communication and exchange, a strong orientation towards application and the privilege to be able to act without linking up with reproductive-disciplinary communities.

Building on the basic models of addition, interaction and synthesis, the authors of this volume have attempted to pinpoint the academic practice that has already emerged after eight months of project work as a snapshot and develop an ambitious, but realistic vision for further collaboration. Looking back, what has become clear is that the collaboration varied depending on the specific aspect of the research process and that it is difficult to define it in a nutshell: a point frequently emphasized was the wide thematic variety of case studies reflected in this volume, which made an actual exchange between the authors difficult; but at the same time the overarching topical areas structuring the research context (see chapters 3, 4 and 5) as well as the theoretical-conceptual tools (see chapter 2) were highlighted, which virtually call for a productive interaction of all the participating authors. Attention was also given to the methods used, however in equal measure as means of addition and of interaction. This initial assessment already makes clear that the academic practice that was quick to establish itself among our contributors oscillated between disciplinary addition and interaction.

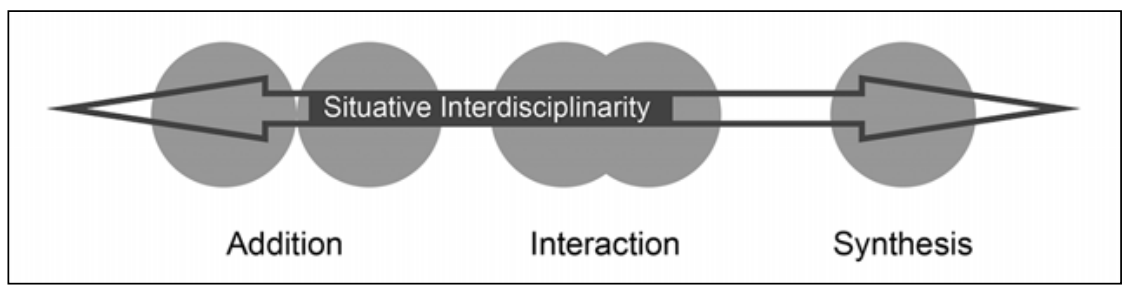

Figure 4: Basic models of cross-disciplinary collaboration (continuum) and position of the concept of situative interdisciplinarity (design: Christian Wille)

In order to reinforce and develop the cross-disciplinary collaboration in the further process of the project, the first experiences were taken on board and, building from these, we developed the concept of situative interdisciplinarity. This common guideline refers to the interaction between the disciplines participating in this volume which did not take place in the same degree at every point of the research process. Rather, it was a matter of limited interactions in specific phases of collaboration considered useful. This was governed by the subject matters and phases that structured the research process such as topics, questions, theories, terms and concepts, methods or interpretation. Interaction between the authors - here understood as interdisciplinarity - were thus not meant to take place as an end in itself, but examined for its added value and implemented depending on 
the situation, during the research process. The following stages were considered particularly suited for this:

1. The development of theoretical-conceptual frameworks within the topic areas (see the introductory sections 3.1, 4.1 and 5.1);

2. The development of common tools of research and analysis (questionnaire, interview guideline);

3. The joint interpretation of empirical data.

A systematic and critical evaluation of the practical implementation of situative interdisciplinarity was only possible after finalizing this book manuscript. Nevertheless, the results of a written survey among 16 authors in an internal colloquium provide first insights into the practice of situative interdisciplinarity and thus into the genesis of this volume. The selected assessments (see Tables 4,5 and 6) seek to reproduce a broad range of opinions on different aspects of the collaboration and in particular point to the challenges of situative interdisciplinarity.

\begin{tabular}{|l|l|}
\hline Positive Assessments & Negative Assessments \\
\hline $\begin{array}{l}\text { "The case study connects my } \\
\text { disciplinary perspective with aspects } \\
\text { know in the workgroup meetings." }\end{array}$ & $\begin{array}{l}\text { "No, research topic, sources etc. are } \\
\text { (too) different from the other case } \\
\text { studies." }\end{array}$ \\
\hline $\begin{array}{l}\text { "Yes, because I work on a corpus } \\
\text { mith methods that transcend } \\
\text { my discipline. In addition, I'm } \\
\text { unknownow in my discipline."78 }\end{array}$ & $\begin{array}{l}\text { "The case study is only partly } \\
\text { interdisciplinary, since I continually } \\
\text { need to coordinate with my } \\
\text { colleagues (of other disciplines) } \\
\text { and this has an influence on the } \\
\text { fundamental perspective on the topic } \\
\text { as well as on the analytical approach. } \\
\text { On the other hand, the case study is } \\
\text { hardly interdisciplinary since I work } \\
\text { on the interface of various disciplines } \\
\text { anyway." }\end{array}$ \\
\hline
\end{tabular}

Table 4: Assessment of the interdisciplinary nature of the authors' own case studies (selected opinions) (University of Luxembourg, IDENT2 2013 - internal survey among the authors)

77 | Personal translation of: "Oui, parce que je travaille sur un corpus et surtout avec des méthodes qui dépassent ma discipline; par ailleurs je suis confronté avec des théories inconnues dans ma discipline." 


\begin{tabular}{|l|l|}
\hline Positive Assessments & Negative Assessments \\
\hline $\begin{array}{l}\text { "I've received constructive criticism } \\
\text { in the sense that I carefully observed } \\
\text { how colleagues in other disciplines } \\
\text { work and argue. This makes me } \\
\begin{array}{l}\text { question my own work methods and } \\
\text { develop a better understanding for } \\
\text { positions foreign to my field." }\end{array}\end{array}$ & $\begin{array}{l}\text { "I have to admit, I don't master the } \\
\text { other colleagues seem to have. I } \\
\text { I believe I can have some command } \\
\text { over."79 }\end{array}$ \\
\hline $\begin{array}{l}\text { "In the workgroup, the exchange } \\
\text { between the disciplines was fairly } \\
\text { good, marked by mutual respect and } \\
\text { interest." }\end{array}$ & $\begin{array}{l}\text { "Some disciplines seemed to be } \\
\text { concepts and terms were adopted } \\
\text { from them." }\end{array}$ \\
\hline $\begin{array}{l}\text { "No rank pulling, the doctoral } \\
\text { candidates collaborated on a } \\
\text { completely equal footing and often } \\
\text { even provided valuable incentives." }\end{array}$ & $\begin{array}{l}\text { "Academic rank influenced the } \\
\text { choice of topics." }\end{array}$ \\
\hline $\begin{array}{l}\text { "I didn't notice any conflicts or } \\
\text { showing-off between individual } \\
\text { people. It was a good cooperative } \\
\text { collaboration." }\end{array}$ & $\begin{array}{l}\text { "Very diverse characters, timid, } \\
\text { reticent, others very sure of } \\
\text { themselves, result-oriented; others } \\
\text { who pondered for a long time } \\
\text { on fundamental questions. This } \\
\text { mixture is probably more difficult } \\
\text { to manage than interdisciplinary } \\
\text { collaboration or the different } \\
\text { academical positions." }\end{array}$ \\
\hline
\end{tabular}

Table 5: Assessment of the collaboration in workgroups (selected opinions) (University of Luxembourg, IDENT2 2013 - internal survey among the authors)

78 | Personal translation of: "J'avoue ne pas maîtriser le background interdisciplinaire que semblent partager les autres membres du groupe. Je préfère n'intervenir que sur ce que je crois pouvoir maîtriser."

79 | Personal translation of: "Pas de rank pulling; les doctorants ont participé de manière tout à fait égalitaire et ont même souvent donné des incentives très précieux."

$\mathbf{8 0}$ | Personal translation of: "Tempéraments très différents, des timides, des réticents, des personnes très convaincues d'elles-mêmes, des gens orientés vers le résultat, d'autres qui restent penchés sur des questions de fond: ce mélange est probablement plus difficile à gérer que le mélange interdisciplinaire et de différents statuts académiques." 


\begin{tabular}{|l|l|}
\hline Positive Assessments & Negative Assessments \\
\hline $\begin{array}{l}\text { "I got to know many colleagues better } \\
\text { and learned something about their } \\
\text { work methods." }\end{array}$ & $\begin{array}{l}\text { "Sometimes it was difficult in the } \\
\text { work meetings to follow up on the } \\
\text { last meeting." }\end{array}$ \\
\hline $\begin{array}{l}\text { "Read various texts which were } \\
\text { extremely productive also for my own } \\
\text { field of research; the opportunity to } \\
\begin{array}{l}\text { work with interesting people (when } \\
\text { they happened to be present)." }\end{array}\end{array}$ & $\begin{array}{l}\text { "Sometimes I'm lost; the discussions } \\
\text { are only helpful in a rather limited } \\
\text { interdisicplinarity has its limits." }\end{array}$ \\
\hline $\begin{array}{l}\text { "For me the project was a great } \\
\text { challenge, since I have no experience } \\
\text { with interdisciplinary work as it is } \\
\text { practiced here. In this sense the } \\
\text { project was very helpful even if just } \\
\text { to understand how interesting it can } \\
\text { be, but also how challenging." }\end{array}$ & $\begin{array}{l}\text { "A considerable expenditure of time } \\
\text { one could avoid; the initial theories } \\
\text { developed in the groups were later } \\
\text { dropped again; intensive research } \\
\text { work in no relation to the size of the } \\
\text { contribution in the book manuscript; } \\
\text { relatively numerous small internal } \\
\text { deadlines, here it was sometimes } \\
\text { difficult not to lose sight of the bigger } \\
\text { picture." }\end{array}$ \\
\hline
\end{tabular}

Tabelle 6: Overall assessment of the collaboration (selected opinions) (University of Luxembourg, IDENT2 2013 - internal survey among the authors)

The concept of situative interdisciplinarity should be understood as a temporary and variable intermeshing of the basic models of addition and interaction. It provides a realistic guideline for the cross-disciplinary collaboration in larger cooperative contexts without dissolving disciplines or fundamentally questioning the familiar academic practice of those involved. Rather it is a matter of partially breaking open self-referential research practices as well as a productive combination of 'disciplinary clichés' in favour of intellectual exchange and progress in knowledge.

81 | Personal translation of: "Sentiment parfois de n'importe quoi ; de discussions me semblant mener à un résultat bien limité. J'ai ressenti des limites réelles à l'idée d'interdisciplinarité."

82 | Personal translation of: "Pour moi le projet était un grand défi, n'ayant pas l'expérience du travail interdisciplinaire comme il s'est fait ici. En ce sens, cela m'a certainement apporté beaucoup si ce n'est de comprendre à quel point cela peut être intéressant mais aussi demandant." 


\subsection{References}

Abels, Heinz (2006): Identität. Über die Entstehung des Gedankens, dass der Mensch ein Individuum ist, den nicht leicht zu verwirklichenden Anspruch auf Individualität und die Tatsache, dass Identität in Zeiten der Individualisierung von der Hand in den Mund lebt, Wiesbaden: Verlag für Sozialwissenschaften.

Albert, Mathias/Brock, Lothar (1996): "Debordering the World of States. New Spaces in International Relations", in: New Political Science 18/1, 69-106.

Allmendinger, Phil/Haughton, Graham (2009): "Soft Spaces, Fuzzy Boundaries, and Metagovernance: The New Spatial Planning in the Thames Gateway", in: Environment and Planning A 41, 617-633.

Althusser, Louis (1971 [1970]): “Ideology and Ideological State Apparatuses" (trans. Ben Brewster), in: L. Althusser (ed.), Lenin and Philosophy and other Essays, New York: Monthly Review Press, 121-176.

Anderson, Benedict (2006): Imagined Communities: Reflections on the Origin and Spread of Nationalism, London/New York: Verso.

Audehm, Kathrin/Velten, Hans Rudolf (2007): “Einleitung”, in: Kathrin Audehm/ Hans Rudolf Velten (eds.), Transgression - Hybridisierung - Differenzierung. Zur Performativität von Grenzen in Sprache, Kultur und Gesellschaft (= Scenae, vol. 4), Freiburg i. Br./Berlin/Wien: Rombach, 9-40.

Avanza, Martina/Laferté, Gilles (2005): "Dépasser la 'construction des identités'? Identification, image sociale, appartenance”, in: Genèses 61, 134-152.

Bachmann-Medick, Doris (2006): Cultural Turns. Neuorientierungen in den Kulturwissenschaften, Reinbek bei Hamburg: Rowohlt.

Bathelt, Harald/Glückler, Johannes (2012): Wirtschaftsgeographie: ökonomische Beziehungen in räumlicher Perspektive, Stuttgart: UTB.

Beck, Ulrich/Giddens, Anthony/Lash, Scott (1994): Reflexive Modernization: Politics, Tradition and Aesthetics in the Modern Social Order, Stanford: Stanford University Press.

Beck, Ulrich/Beck-Gernsheim, Elisabeth (2001): Individualization: Institutionalized Individualism and its Social and Political Consequences, London/Thousand Oaks: Sage.

Beetham, Gwendolyn/Fernández, Melissa (2010): "Inter/Trans/Post-Disciplinarity: Explorations of Encounters across Disciplines", in: Graduate Journal of Social Science 7, 7-13.

Benjamin, Walter (1999): The Arcades Project, prepared on the basis of the German volume ed. by Rolf Tiedemann (trans. Howard Eiland and Kevin McLaughlin), Cambridge MA: The Belknap Press of Harvard University Press.

Boeckler, Marc (2012): "Borderlands", in: Nadine Marquardt/Verena Schreiber (eds.), Ortsregister. Ein Glossar zu Räumen der Gegenwart, Bielefeld: transcript, 44-49. 
Böckler, Stefan (2007): “Grenze und frontier: Zur Begriffs- und Sozialgeschichte zweier Schließungsparadigmen der Moderne”, in: Petra Deger/Robert Hettlage (eds.), Der europäische Raum. Die Konstruktion europäischer Grenzen, Wiesbaden: Verlag für Sozialwissenschaften, 25-48.

Bourdieu, Pierre (1972): Esquisse d'une théorie de la pratique. Précédé de trois études d'ethnologie kabyle, Paris: Seuil.

Bourdieu Pierre, (1980): Le sens pratique, Paris, Minuit.

Bröckling, Ulrich/Krasmann, Susanne/Lemke, Thomas (2000): “Gouvernementalität, Neoliberalismus und Selbst-technologien. Eine Einleitung”, in: Ulrich Bröckling/Susanne Krasmann/Thomas Lemke (eds.), Gouvernementalität der Gegenwart. Studien zur Ökonomisierung des Sozialen, Frankfurt a. M.: Suhrkamp, 7-40.

Brubaker, Rogers (2001): “Au-delà de l'identité", in: Actes de la recherche en sciences sociales 139, 66-85.

Bühler, Benjamin (2012): “Grenze. Zur Wort- und Theoriegeschichte”, in: Trajekte 24, 31-34.

Bührmann, Andrea/Schneider, Werner (2008): Vom Diskurs zum Dispositiv.

Eine Einführung in die Dispositivanalyse, Bielefeld: transcript.

Butler, Judith (2006 [1990]): Gender Trouble, London/New York: Routledge.

Butler, Judith (2008a [1990]): “Bodily Inscriptions, Performative Subversions”, in:

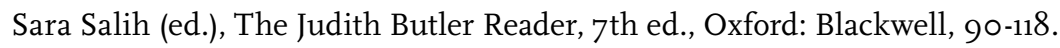

Butler, Judith (2008b [1990]): “Imitation and Gender Insubordination", in: Sara

Salih (ed.), The Judith Butler Reader, 7th ed., Oxford: Blackwell, 119-137.

Chaffee, Daniel (2011): “Reflexive Identities”, in: Anthony Elliott (ed.), Routledge

Handbook of Identity Studies, London/New York: Routledge, 100-111.

de Certeau, Michel (1984 [French original 1980]): The Practice of Everyday Life

(trans. Steven Rendall), Berkeley/Los Angeles: University of California Press.

Derrida, Jacques (1982a [French original 1978]): The Truth in Painting (trans.

Geoff Bennington and Ian McLeod), Chicago: University of Chicago Press.

Derrida, Jacques (1982b [French original 1978]): "Différance” (trans. Alan Bass),

in: Margins of Philosophy, Chicago: University of Chicago Press, 3-27.

Després, Carole/Lawrence, Roderick J. (2004): “Introduction”, in: Futures 36, 397405.

Döring, Jörg (2010): “Spatial Turn”, in: Stephan Günzel (ed.), Raum. Ein interdisziplinäres Handbuch, Stuttgart: Metzler, 90-99.

Eigmüller, Monika (2006): “Der duale Charakter der Grenze. Bedingungen einer aktuellen Grenztheorie”, in: Monika Eigmüller/Georg Vobruba (eds.), Grenzsoziologie. Die politische Strukturierung des Raums, Wiesbaden: Verlag für Sozialwissenschaften, 55-73.

Elias, Norbert (1986): “Figuration”, in: Bernhard Schäfers (ed.), Grundbegriffe der Soziologie, Opladen: Leske + Budrich, 88-91.

Elliott, Anthony (ed.) (2011): Routledge Handbook of Identity Studies, London/ New York: Routledge. 
Emirbayer, Mustafa (1997): “Manifesto for a Relational Sociology”, in: American Journal of Sociology 103/2, 281-317.

Faber, Richard/Naumann, Barbara (eds.) (1995): Literatur der Grenze - Theorie der Grenze, Würzburg: Königshausen \& Neumann.

Fischer-Lichte, Erika (2005): “Grenze oder Schwelle? Zum Verhältnis von Kunst und Leben”, in: Sprache und Literatur 36, 3-14.

Flusser, Vilém (1996): Zwiegespräche. Interviews 1967-1991, Göttingen: European Photography.

Flusser, Vilém (2009): Kommunikologie weiter denken. Die Bochumer Vorlesungen, Frankfurt a.M.: Fischer.

Foucault, Michel (1977 [French original 1975]): Discipline and Punish: The Birth of the Prison (trans. Alan Sheridan), New York: Pantheon Books.

Foucault, Michel (1982): “The Subject and Power“, in: Hubert Dreyfus/Paul Rabinow, Michel Foucault. Beyond Structuralism and Hermeneutics (trans. Robert Hurley et. al), Chicago: The University of Chicago Press, 208-226.

Foucault, Michel (1993): "About the Beginning of the Hermeneutics of the Self" (orig. in English, ed. by Thomas Keenan and Mark Blasius), in: Political Theory, vol. 21/2,198-227.

Foucault, Michel (1998 [French original 1963]) "A preface to transgression" (trans. Donald F. Bouchard and Sherry Simon, slightly modified), in: James D. Faubion (ed.), Aesthetics, method and epistemology, New York: New Press, 69-87.

Foucault, Michel (2007 [French original 2004]): Security, Territory, Population. Lectures at the Collège de France, 1977-1978 (trans. Graham Burchell), New York: Picador.

Füller, Henning/Marquardt, Nadine, (2009): "Gouvernementalität in der humangeographischen Diskursforschung”, in: Georg Glaszke/Annika Mattissek (eds.), Handbuch Diskurs und Raum. Theorien und Methoden für die Humangeographie sowie die sozial- und kulturwissenschaftliche Raumforschung, Bielefeld: transcript, 83-106.

Gertenbach, Lars (2012): "Governmentality Studies. Die Regierung der Gesellschaft im Spannungsfeld von Ökonomie, Staat und Subjekt”, in: Stephan Moebius (ed.), Kultur. Von den Cultural Studies bis zu den Visual Studies. Eine Einführung, Bielefeld: transcript, 109-127.

Giddens, Anthony (1991): Modernity and Self-Identity: Self and Society in the Late Modern Age, Cambridge: Polity Press.

Goffman, Erving (1974): Frame Analysis. An Essay on the Organization of Experience, Boston: Northeastern University Press.

Goffman, Erving (1959): The Presentation of Self in Everyday Life, New York: Anchor Books.

Graumann, Carl Friedrich (1983): “On Multiple Identities”, in: International Social Science Journal 35, 309-321.

Greverus, Ina-Maria (1995): Die Anderen und Ich, Darmstadt: Wissenschaftliche Buchgesellschaft. 
Guldin, Rainer (2011): “Ineinander greifende graue Zonen. Vilém Flussers Bestimmung der Grenze als Ort der Begegnung”, in: Christoph Kleinschmidt/ Christine Hewel (eds.), Topographien der Grenze. Verortungen einer kulturellen, politischen und ästhetischen Kategorie, Würzburg: Königshausen \& Neumann, 39-48.

Halpern, Catherine (2009): Identité(s). L'individu, le groupe, la société, Paris: Editions Sciences Humaines.

Han, Sam (2011): “The Fragmentation of Identity Theories”, in: Anthony Elliott (ed.), Routledge Handbook of Identity Studies, London/New York: Routledge, 83-99.

Harendt, Annegret/Sprunk, Dana (2011): “Erzählter Raum und Erzählraum: (Kultur-)Raumkonstruktion zwischen Diskurs und Performanz”, in: Social Geography $6,15-27$.

Hark, Sabine (2005): “Inter/Disziplinarität. Gender Studies Revisited”, in: Heike Kahlert/ Barbara Thiessen/Ines Weller (eds.), Quer denken - Strukturen verändern. Gender Studies zwischen Disziplinen, Wiesbaden: Verlag für Sozialwissenschaften, 61-89.

Heckhausen, Heinz (1987): “Interdisziplinäre Forschung zwischen Intra-, Multi- und Chimären-Disziplinarität”, in: Jürgen Kocka (ed.), Interdisziplinarität: Praxis - Herausforderung - Ideologie, Berlin: Suhrkamp, 129-145.

Hipfl, Brigitte (2004): “Mediale Identitätsräume. Skizzen zu einem 'spatial turn' in der Medien- und Kommunikationswissenschaft”, in: Brigitte Hipfl/Elisabeth Klaus/Uta Scheer (eds.), Identitätsräume. Nation, Körper und Geschlecht in den Medien. Eine Topografie, Bielefeld: transcript, 16-50.

van Houtum, Henk/van Naerssen, Ton (2002): "Bordering, Ordering and Othering”, in: Journal of Economic and Social Geography 93/2, 125-136.

IPSE (2010) (ed.): Doing Identity in Luxemburg. Subjektive Aneignungen - institutionelle Zuschreibungen - sozio-kulturelle Milieus, Bielefeld: transcript.

IPSE (2011a) (ed.): Doing Identity in Luxembourg. Subjective Appropriations - Institutional Attributions - Socio-Cultural Milieus, Bielefeld: transcript.

IPSE (2011b) (ed.): Construire des identités au Luxembourg. Appropriations subjectives - Projections institutionnelles - Milieux socio-culturels, Paris: Berg International.

Jungert, Michael (2010): “Was zwischen wem und warum eigentlich? Grundsätzliche Fragen der Interdisziplinarität”, in: Michael Jungert/Elsa Romfeld/Thomas Sukopp/Uwe Voigt (eds.), Interdisziplinarität. Theorie, Praxis, Probleme, Darmstadt: Wissenschaftliche Buchgesellschaft, 1-11.

Kajetzke, Laura/Schroer, Markus (2010): “Sozialer Raum: Verräumlichung”, in: Stephan Günzel (ed.), Raum. Ein interdisziplinäres Handbuch, Stuttgart: Metzler, 192-203.

Kalscheuer, Britta (2005): “Die raum-zeitliche Ordnung des Transdifferenten”, in: Lars Allolio-Näcke/Britta Kalscheuer/Arne Manzeschke (eds.), Differenzen 
anders denken. Bausteine zu einer Kulturtheorie der Transdifferenz, Frankfurt a.M.: Campus, 68-85.

Kaufmann, Stefan/Bröckling, Ulrich/Horn, Eva (2002): “Einleitung”, in: Stefan Kaufmann/Ulrich Bröckling/Eva Horn (eds.), Grenzverletzer. Von Schmugglern, Spionen und anderen subversiven Gestalten, Berlin: Kulturverlag Kadmos, 7-22.

Keupp, Heiner/Ahbe, Thomas/Gmür, Wolfgang/Höfer, Renate/Mitzscherlich, Beate/Kraus, Wolfgang/Straus, Florian (2006): Identitätskonstruktionen. Das Patchwork der Identitäten in der Spätmoderne, Reinbek bei Hamburg: Rowohlt.

Krappmann, Lothar (2005): Soziologische Dimensionen der Identität. Strukturelle Bedingungen für die Teilnahme an Interaktionsprozessen, Stuttgart: KlettCotta.

Lahire, Bernhard (1998): L'homme pluriel. Les ressorts de l'action, Paris: Nathan. Lamping, Dieter (2001): Über Grenzen - eine literarische Topographie, Göttingen: Vandenhoek \& Ruprecht.

Lask, Tomke (2002): "Wir waren doch immer Freunde in der Schule". Einführung in die Anthropologie der Grenzräume - Europäisches Grenzverständnis am Beispiel Leidingens, Saarbrücken: Röhrig.

Lefebvre, Henri (1991 [French Original 1974]): The Production of Space (trans. Donald Nicholson-Smith), Oxford: Blackwell.

Lemke, Thomas (2008): “Gouvernementalität”, in: Clemens Kammler (ed.), Foucault-Handbuch. Leben - Wirkung - Werk, Stuttgart/Weimar: Verlag J. B. Metzler, 260-263.

Löffler, Winfried (2010): "Vom Schlechten des Guten: Gibt es schlechte Interdisziplinarität?”, in: Michael Jungert/Elsa Romfeld/Thomas Sukopp/Uwe Voigt (eds.), Interdisziplinarität. Theorie, Praxis, Probleme, Darmstadt: Wissenschaftliche Buchgesellschaft, 157-172.

Lösch, Klaus (2005): "Begriff und Phänomen der Transdifferenz: Zur Infragestellung binärer Differenzkonstrukte”, in: Lars Allolio-Näcke/Britta Kalscheuer/ Arne Manzeschke (eds.), Differenzen anders denken. Bausteine zu einer Kulturtheorie der Transdifferenz, Frankfurt a.M.: Campus, 26-49.

Lossau, Julia (2002): Die Politik der Verortung. Eine postkoloniale Reise zu einer "ANDEREN" Geographie der Welt, Bielefeld: transcript.

Lossau, Julia (2003): "Geographische Repräsentationen: Skizze einer anderen Geographie”, in: Hans Gebhardt/Paul Reuber/Günther Wolkersdorfer (eds.), Kulturgeographie. Aktuelle Ansätze und Entwicklungen, Heidelberg/Berlin: Spektrum Akademischer Verlag, 101-111.

Maihofer, Andrea (2005): "Inter-, Trans- und Postdisziplinarität. Ein Plädoyer wider die Ernüchterung”, in: Heike Kahlert/Barbara Thiessen/Ines Weller (eds.), Quer denken - Strukturen verändern. Gender Studies zwischen Disziplinen, Wiesbaden: Verlag für Sozialwissenschaften, 185-202. 
Mayring, Philipp (2002): Einführung in die qualitative Sozialforschung, Weinheim: Beltz.

Medick, Hans (1995): "Grenzziehungen und die Herstellung des politisch-sozialen Raumes. Zur Begriffsgeschichte und politischen Sozialgeschichte der Grenzen und der frühen Neuzeit", in: Richard Faber/Barbara Naumann (eds.), Literatur der Grenze - Theorie der Grenze, Würzburg: Königshausen \& Neumann, 211-224.

Moebius, Stephan (2008): "Handlung und Praxis. Konturen einer poststrukturalistischen Praxistheorie”, in: Stephan Moebius/Andreas Reckwitz (eds.), Poststrukturalistische Sozialwissenschaften, Frankfurt a.M.: Suhrkamp, 58-74.

Neumann, Birgit (2009): "Imaginative Geographien in kolonialer und postkolonialer Literatur: Raumkonzepte der (Post-)Kolonialismusforschung”, in: Wolfgang Hallet/Birgit Neumann (eds.), Raum und Bewegung in der Literatur. Die Literaturwissenschaften und der Spatial Turn, Bielefeld: transcript, 115-138.

Newman, Davis (2001): "Boundaries, Borders, and Barriers: Changing Geographic Perspectives on Territorial Lines", in: Mathias Albert/David Jacobson/ Yosef Lapid (eds.), Identities, Borders, Orders. Rethinking International Relations Theory, Minnesota: University of Minnesota, 137-151.

Parr, Rolf (2008): "Liminale und andere Übergänge. Theoretische Modellierungen von Grenzzonen, Normalitätsspektren, Schwellen, Übergängen und Zwischenräumen in Literatur- und Kulturwissenschaft", in: Achim Geisenhanslüke/Georg Mein (eds.), Schriftkultur und Schwellenkunde, Bielefeld: transcript, $11-6_{3}$.

Reckwitz, Andreas (2001): "Der ldentitätsdiskurs zum Bedeutungswandel einer sozialwissenschaftlichen Semantik", in: Werner Rammert/Gunther Knauthe/ Klaus Buchenau/Florian Altenhoner (eds.), Kollektive Identitäten und Kulturelle Innovationen: ethnologische, soziologische und historische Studien, Leipzig: Leipziger Universitätsverlag, 21-38.

Reckwitz, Andreas (2003): "Grundelemente einer Theorie sozialer Praktiken: Eine sozialtheoretische Perspektive”, in: Zeitschrift für Soziologie 32/4, 282301.

Reckwitz, Andreas (2008): "Praktiken und Diskurse. Eine sozialtheoretische und methodologische Relation", in: Herbert Kalthoff/Stefan Hirschauer/Gesa Lindemann (eds.), Theoretische Empirie. Zur Relevanz qualitativer Sozialforschung, Frankfurt a.M.: Suhrkamp, 188-209.

Reckwitz, Andreas (2010): "Auf dem Weg zu einer kultursoziologischen Analytik zwischen Praxeologie und Poststrukturalismus", in: Monika Wohlrab-Sahr (ed.), Kultursoziologie. Paradigmen - Methoden - Fragestellungen, Wiesbaden: Verlag für Sozialwissenschaften, 179-205.

Reckinger, Rachel/Schulz, Christian/Wille, Christian (2011a): "Preface”, in: IPSE (ed.), Doing Identity in Luxembourg. Subjective Appropriations - Institutional Attributions - Socio-Cultural Milieus, Bielefeld: transcript, 7-9. 
Reckinger, Rachel/Schulz, Christian/Wille, Christian (2011b): “Identity Constructions in Luxembourg”, in: IPSE (ed.), Doing Identity in Luxembourg. Subjective Appropriations - Institutional Attributions - Socio-Cultural Milieus, Bielefeld: transcript, 291-294.

Reckinger, Rachel/ Wille, Christian (2011b): "Researching Identity Constructions”, in: IPSE (ed.), Doing Identity in Luxembourg. Subjective Appropriations - Institutional Attributions - Socio-Cultural Milieus, Bielefeld: transcript, 1134.

Renn, Joachim/Straub, Jürgen (2002): “Transitorische Identität. Der Prozesscharakter moderner personaler Selbstverhältnisse”, in: Joachim Renn/Jürgen Straub (eds.), Transitorische Identität. Der Prozesscharakter des modernen Selbst, Frankfurt a.M.: Campus, 10-31.

Ricoeur, Paul (1992 [French original 1990]): Oneself as Another (trans. Kathleen Blamey), Chicago: University of Chicago Press.

Roll, Christine/Pohle, Frank/Myrczek, Matthias (eds.) (2010): Grenzen und Grenzüberschreitungen. Bilanz und Perspektiven der Frühneuzeitforschung, Köln/Weimar/Wien: Böhlau.

Rosa, Hartmut (2007): “Identität”, in: Jürgen Straub/Arne Weidemann (eds.), Handbuch interkulturelle Kommunikation und Kompetenz. Grundbegriffe Theorien - Anwendungsfelder, Stuttgart: Metzler.

Ruano-Borbolan, Jean-Claude (1998): L'identité. L'individu, le groupe, la société, Auxerre: Sciences Humaines.

Said, Edward W. (1978): Orientalism, New York: Pantheon Books.

Schreiber, Verena (2009): “Raumangebote bei Foucault”, in: Georg Glasze/Annika Mattissek (eds.), Handbuch Diskurs und Raum. Theorien und Methoden für die Humangeographie sowie die sozial- und kulturwissenschaftliche Raumforschung, Bielefeld: transcript, 199-212.

Schroer, Markus (2008): “'Bringing Space Back In' - Zur Relevanz des Raums als soziologische Kategorie”, in: Jörg Döring/Tristan Thielmann (eds.), Spatial Turn. Das Raumparadigma in den Kultur- und Sozialwissenschaften, Bielefeld: transcript, 125-148.

Sennett, Richard (1996): "Etwas ist faul in der Stadt", in: Die Zeit, 26. Januar, 47-48.

Simmel, Georg (1992 [1903]): "Der Raum und die räumlichen Ordnungen der Gesellschaft”, in: Otthein Rammstedt (ed.), Georg Simmel: Soziologie. Untersuchungen über die Formen der Vergesellschaftung (= complete edition, vol. 11), Frankfurt a.M.: Suhrkamp, 687-790.

Soja, Edward W. (1989): Postmodern Geographies: The Reassertion of Space in Critical Social Theory, London: Verso.

Soja, Edward W. (1996): Thirdspace: Journeys to Los Angeles and Other Real-andImagined Places, Oxford: Blackwell. 
Somers, Margaret R./Gibson, Gloria D. (1994): "Reclaiming the Epistemological 'Other': Narrative and the Social Constitution of Identity”, in: Craig Calhoun (ed.), Social Theory and the Politics of Identity, Oxford: Blackwell, 37-99.

Straub, Jürgen (2004): “Identität”, in: Friedrich Jaeger/Burkhard Liebsch (eds.), Handbuch der Kulturwissenschaften. Grundlagen und Schlüsselbegriffe, Stuttgart: Metzler, 277-303.

Turner, Victor (1982): “Liminal to Liminoid, in Play, Flow, and Ritual: An Essay in Comparative Symbology”, in: Victor Turner, Ritual to Theatre: The Human Seriousness of Play, University of Michigan, Ann Arbor: Performing Arts Journal Publications.

van Gennep, Arnold (1960 [French original 1909]): Rites of Passage (trans. Monika B. Vizedom and Gabrielle L. Caffee), Chicago: University of Chicago Press. Wagner, Kirsten (2010): “Topographical Turn”, in: Stephan Günzel (ed.), Raum. Ein interdisziplinäres Handbuch, Stuttgart: Metzler, 100-109.

Walter-Wastl, Doris (ed.) (2011): The Ashgate Research Companion to Border Studies, Farnham: Ashgate.

Warde, Alan/Martens, Lydia/Olsen, Wendy (1999): “Consumption and the Problem of Variety. Cultural Omnivorousness, Social Distinction and Dining out”, in: Sociology 33/1, 105-127.

Warde, Alan (2005): "Consumption and Theories of Practice”, in: Journal of Consumer Culture 5/2, 131-153.

Watkin, Christopher (2009): Phenomenology or Deconstruction? The Question of Ontology in Maurice Merleau-Ponty, Paul Ricoeur, Jean-Luc Nancy, Edinburgh: Edinburgh University Press.

Weichhart, Peter (1990): Raumbezogene Identität. Bausteine zu einer Theorie räumlich-sozialer Kognition und Identifikation, Stuttgart: Franz Steiner Verlag.

Weigel, Sigrid (2002): “Zum ‘topographical turn'. Kartographie, Topographie und Raumkonzepte in den Kulturwissenschaften”, in: KulturPoetik 2/2, 151-165.

Werlen, Benno (1997a): Sozialgeographie alläglicher Regionalisierungen, vol. 2: Globalisierung, Region und Regionalisierung, Stuttgart: Franz Steiner Verlag.

Werlen, Benno (1997b): “Einleitung”, in: Benno Werlen (ed.), Sozialgeographie alltäglicher Regionalisierungen, vol. 3: Ausgangspunkte und Befunde empirischer Forschung, Stuttgart: Franz Steiner Verlag, 9-16.

Werlen, Benno (2008): Sozialgeographie. Eine Einführung, Bern: Haupt.

Werlen, Benno (2009): “Geographie/Sozialgeographie”, in: Stephan Günzel (ed.), Raumwissenschaften, Frankfurt a.M.: Suhrkamp, 142-158.

Werlen, Benno (2010): Gesellschaftliche Räumlichkeit 1. Orte der Geographie, Stuttgart: Franz Steiner Verlag.

Wetherell, Margaret/Mohanty, Chandra Talpade (eds.) (2010): The Sage Handbook of Identities, Los Angeles/London/New Delhi/Singapore/Washington DC: Sage. 
Wiesmann, Urs/Biber-Klemm, Susette/Grossenbacher-Mansuy, Walter/Hirsch Hadorn, Gertrude/Hoffmann-Riem, Holger/Joye, Dominique/Pohl, Christian/Zemp, Elisabeth (2008): “Transdisziplinäre Forschung weiterentwickeln: Eine Synthese mit 15 Empfehlungen”, in: Frédéric Darbellay/Theres Paulsen (eds.), Herausforderung Inter- und Transdisziplinarität. Konzepte, Methoden und innovative Umsetzung in Lehre und Forschung, Lausanne: Presses Polytechniques et Universitaires Romandes, 174-179.

Wille, Christian (2014): "Räume der Grenze. Eine praxistheoretische Perspektive in den kulturwissenschaftlichen Border Studies”, in: Friederike Elias/Albrecht Franz/Henning Murmann/Ulrich Weiser (eds.), Praxeologie. Beiträge zur interdisziplinären Reichweite praxistheoretischer Ansätze in den Geistesund Sozialwissenschaften (=Materiale Textkulturen, vol. 3), Berlin: De Gruyter, $53-72$. 
Christian Wille, Rachel Reckinger, Sonja Kmec, Markus Hesse (eds.)

\section{SPACES AND}

IDENTITIES IN

\section{BORDER REGIONS}

Politics - Media - Subjects

[transcript] Culture and Social Practice 
Christian Wille, Rachel Reckinger, Sonja Kmec, Markus Hesse (eds.) Spaces and Identities in Border Regions

Culture and Social Practice 
E-Book von Christian Wille, christian.wille@uni.lu

27.01.2016 17:18

Copyright 2016, transcript Verlag, Bielefeld 
Christian Wille, Rachel Reckinger, Sonja Kmec, Markus Hesse (eds.)

\section{Spaces and Identities in Border Regions}

Politics - Media - Subjects

\section{[transcript]}




\section{Bibliographic information published by the Deutsche Nationalbibliothek}

The Deutsche Nationalbibliothek lists this publication in the Deutsche Nationalbibliografie; detailed bibliographic data are available in the Internet at http://dnb.d-nb.de

\section{(๔) 2015 transcript Verlag, Bielefeld}

All rights reserved. No part of this book may be reprinted or reproduced or utilized in any form or by any electronic, mechanical, or other means, now known or hereafter invented, including photocopying and recording, or in any information storage or retrieval system, without permission in writing from the publisher.

Cover layout: Kordula Röckenhaus, Bielefeld

Cover illustration: misterQM / photocase.de

English translation: Matthias Müller, müller translations (in collaboration with Jigme Balasidis)

Typeset by Mark-Sebastian Schneider, Bielefeld

Printed in Germany

Print-ISBN 978-3-8376-2650-6

PDF-ISBN 978-3-8394-2650-0 